\title{
Optimizing Rapid Granulator Machines Utilization Using Overall Equipment Effectiveness and Capacity Measurement in Injection Molding at PT MT Indonesia
}

\author{
Thomas Christian ${ }^{1}$, and Hery Hamdi Azwir*2 \\ Industrial Engineering/ Faculty of Engineering, President University, \\ Jl. Ki Hajar Dewantara, Jababeka, Cikarang, Bekasi, 17530, Indonesia \\ Email: christhoms81@gmail.com ${ }^{1}$, hery.azwir@president.ac.id*2
}

\begin{abstract}
Abstrak
Produktivitas yang rendah dapat dipengaruhi oleh beberapa kondisi seperti downtime alat berat, kinerja operator, perencanaan kapasitas yang tidak efisien dan prosedur operasi yang tidak tepat. Cara yang paling efektif untuk mengetahui solusi dari masalah ini adalah dengan menghitung utilisasi mesin. Tujuan dari penelitian ini adalah untuk mengoptimalkan mesin Rapid Granulator di area injection moulding dengan menggunakan observasi Day in the Life Of (DILO), Overall Equipment Effectiveness (OEE) dan pengukuran kapasitas. Penelitian ini akan menganalisis metrik perhitungan yang sesuai untuk mengukur utilisasi mesin Rapid Granulator dengan membandingkan kapasitas mesin, waktu operasi yang direncanakan, pemeliharaan pencegahan yang direncanakan dan jumlah mesin yang dibutuhkan. Dalam dua tahun terakhir diharapkan tingkat efisiensi selalu meningkat hingga mencapai 95\% dengan rata-rata Tingkat utilisasi PT. MT Indonesia sebesar 85\%. Namun, tidak ada standar atau cara terpadu untuk mengukur tingkat utilisasi mesin dan karena banyaknya variasi mesin, tidak semuanya memiliki metrik perhitungan. Pengamatan lebih lanjut menunjukkan bahwa mesin Rapid Granulator yang berada di area Injection Moulding PT. MT Indonesia tidak pernah dihitung dan tingkat utilisasi yang rendah dapat dilihat setelah dilakukan studi waktu. Sebuah sampel dari 16 mesin diukur dengan hanya 23\% dari tingkat utilisasi dalam satu waktu operasi shift. Hasilnya kemudian menunjukkan bahwa tindakan perbaikan untuk mengurangi jumlah mesin dari 105 menjadi 24 akan meningkatkan tingkat utilisasi hingga 87\% dengan skor OEE meningkat dari 1,8\% menjadi 39\%. Dengan demikian, PT. MT Indonesia dapat meminimalkan biaya seperti yang diharapkan dalam perhitungan biaya dan mengoptimalkan penggunaan mesin Rapid Granulator.
\end{abstract}

Kata kunci: Day in the Life Of (DILO), Pengukuran Kapasitas, Pemeliharaan Pencegahan, Metrik Perhitungan, Perencanaan Kapasitas, Pemanfaatan Mesin, Efektivitas Peralatan Keseluruhan (OEE)

\begin{abstract}
Low productivity can be affected by several conditions like machine downtime, operator performance, inefficient capacity planning, etc. The most effective way to find out the solution to this problem is to calculate machine utilization. The purpose of this research is to optimize Rapid Granulator machines in the injection molding area. The methods used for this research are Day in the Life Of (DILO) observation, Overall Equipment Effectiveness (OEE), and capacity measurement. The research will analyze the suitable calculation metric to measure Rapid Granulator machines utilization by comparing machine capacity, planned run time, planned preventive maintenance, and the number of machines needed. In the last two years, the expected efficiency rate is always increasing up to $95 \%$ with the average of PT. MT Indonesia utilization rate of $85 \%$. However, there are no standards or unified way to measure a machine's utilization rate and due to the huge variety of machinery not all of them have the calculation metrics. Further observation shows that Rapid Granulator machines that located in the Injection Molding area of PT. MT Indonesia has never been calculated and the low utilization rate can be seen after a quick time study. A sample of 16 machines is measured with only $23 \%$ of utilization rate in one shift operation time. The total runner weight is measured to calculate the required capacity. The capacity utilization is then measured by comparing the machine's available capacity (from DILO) and required capacity. The result then shows that the improvement activities to reduce the number of machines from 105 to 24 will increase the utilization rate up to $87 \%$ with the OEE score increasing from $1.8 \%$ to $39 \%$. Thus, PT. MT Indonesia can minimize cost as expected in the cost calculation and optimize Rapid Granulator machines usage.
\end{abstract}

Keywords: Day in the Life Of (DILO), Capacity Measurement, Capacity Planning, Machine Utilization, Overall Equipment Effectiveness (OEE)

\section{Introduction}

In the era of Industrial 4.0, a vast advancement of technology had given a huge change in the manufacturing industries. Significant development of machinery has slowly replaced human interfere in the production processes. With the existence of this trend, manufacturing industries have to adjust and follow the technology advancement to survive. On the other hand, consumer demand has greatly influencing industrial's competitiveness as customers developed a need for a lower price, high quality, and instant product. These occurrences had forced every manufacturing industry to improve productivity and also the use of technology. Every manufacturing industries have to generate a good strategy to utilize their machine and equipment, for it is, in fact, one of the most contributing factors to a company's performance and productivity. As (Kutucuoglu, Hamali, Irani, \& Sharp, 2001) had stated that the major contributor to the profitability and performance in manufacturing is machine and equipment.

As one of the biggest toy manufacturing companies that specialize in dolls production, PT. MT Indonesia has been running with a high standard of performance. In the last two years, the expected efficiency rate is always increasing up to $95 \%$ with the average of PT. MT Indonesia utilization rate of $85 \%$.

Rapid Granulator Machine was established in 1942 by the request of local plastic molders to develop a machine to ease them grinding up plastic material. The granulator machine builds up with several fixed knives or blades, a disposable rotatably rotor in the granulator mill 
housing, and a discharge section to discharge any input plastic material (United States Patent No. US 8,464,973 B2, 2013). The use of rapid machine granulators in the plastic industry is necessary for regrinding and recycling waste or excess plastic materials.

The rapid granulator's interior can be accessible for cleaning since it is necessary to clean the interior before changing the color or quality of plastic material. PT. MT Indonesia has three types of rapid granulator machines divided by their blades ( 3 blades, 4 blades, and 5 blades). Rapid granulator with more blades could grind faster than the lesser blades but also comes with higher power consumption.

Further observation shows that Rapid Granulator machines that located in the Injection Molding area of PT. MT Indonesia has never been calculated and the low utilization rate can be seen after a quick time study. PT. MT Indonesia used different kinds of materials to produce the main structure of a doll, but not all the materials are used for the finished goods. Some of them are being processed to be a runner, cavity, or connector to ease the Injection Molding process.

Overall Equipment Effectiveness (OEE) can be applied to several levels and aspects within a production environment. OEE can function as a benchmark for estimating initial performance whether it is per machine or an overall plant. The initial OEE can also be compared with the future OEE values to identify and calculating improvement that has been made. Furthermore, OEE calculation can be used to compare performance between lines, or areas within the factory, thereby any poor performance found can be highlighted and easily identified (Nakajima, 1988).

In PT. MT Indonesia, a Rapid granulator machine works individually processing different types of material, hence the worst machine performance can be identified using OEE performance calculation. OEE is measured in the consideration of six big losses, which are practical can be calculated through availability, performance, and quality rate of the particular machine, line, plant, or whichever is the focus of the OEE calculation. OEE score can also indicate a complete measurement of machine efficiency. The relation between OEE and six big losses are availability loss (equipment failure and set-up \& adjustment), performance loss (idling \& minor stops and reduced speed), and quality loss (process defects and reduce yield).

This research will deep-dive analyze the Rapid Granulator machine performance with the goal to increase its utilization rate. The focus of this research is to increase utility with the addition of improving OEE (Overall Effectiveness Equipment) and energy cost saving. With this study, it is expected that Rapid Granulator machines usage can be optimized through a proposed method and the operating cost can be minimized as expected in the cost calculation. The importance of this research is because the Rapid Granulator machines are producing unnecessary expenses such as maintenance cost, material handling time, and excessive electrical cost. The contribution of this research will reduce cost for operation and increasing machine performance as well as utilization rate to meet PT. MT's standard of operation.

\section{Research Method}

This section will explain some concepts that were used in the research and the methodology implemented to do the analysis and improvement.

\subsection{Machine Mapping}

Mapping equipment or facility machines will enormously enhance the advancement of a route-based manufacturing program. Machine mapping is necessarily needed for preceding plants where there are no documentaries for changes or have never been documented before. Machine mapping should give enough information about the route (linear sequence) so it can be visually devised and easy to follow. In addition, Computerized Maintenance Management System (CMMS) and other machine's management systems can be validated through machine mapping that accommodates machine numbers and complete visualization of asset's description. (Ward, 2017).

\subsection{Day in the Life of (DILO)}

Day in the Life of (DILO) is one observation method to observe an individual or a process as performed in an everyday job. It is a detailed form of time study in which the observer records every activity done with comments, quotes, or any other data required. This observation method has the purpose to gather a detailed understanding of the process or job and searching for operational issues that came upon in the daily work environment. This approach is done to identify the causes of non-value-added operational activities as well as their quantities and types. Day in the Life of (DILO) observation is best applied to a repetitive job whether it is an operator or a machine. It will not be possible to use DILO in a job with high complexity and are not repetitive. The operational DILO observation analysis can be led to estimation or calculation of how the rate of non-value-added activities could be minimized, through root cause analysis and understanding. Even though there are no benchmarks exist to what constitutes a good ratio between value-added and non-value-added activities, PT. MT Indonesia has been working with the standard of more than 80 to $85 \%$ value-added tasks. With the DILO observation method, it is hoped that the rate of the valueadded task of rapid granulator machines can be calculated with the assumption of one-day observation will represent the current operational process.

\subsection{Measuring Machine Efficiency}

In production processes, there is a planned shift length that can be categorized into two, which are planned operation time and planned downtime. Planned operation time is proposed by the management and can be considered as a standard time for a production process in one shift. On the other hand, planned downtime is the allowance decided by the management to stop or cease production process due to certain unavoidable conditions such as operator's utilities, cleaning process, changeover, preventive maintenance, low demand, etc. These two factors are included in the measurement of machine efficiency and manpower utilization as industries will try to maximize the actual operation time while reducing the 
unplanned downtime to increase available capacity and utilization. The production shift breakdown will be explained in Figure 1.

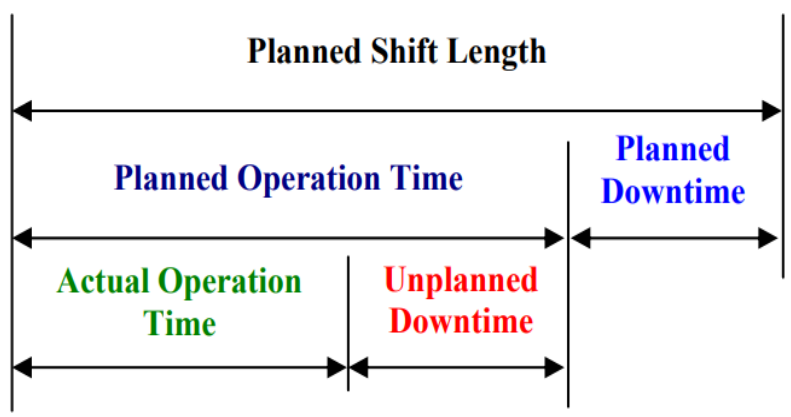

Figure 1. Production Shift Breakdown

In the measurement of machine efficiency, planned downtime should be subtracted from the overall shift length. This is done to exclude all the events with no intention of production running in it such as maintenance schedule, breaks, planned production stop, etc. from the efficiency analysis. All the conditions that stop planned operation time are categorized as unplanned downtime. It can be happened because of several factors such as machine failures, problems in quality, shortages, changeover-time, etc. (Subramaniam, Husin, Yusop, \& Hamidon, 2008).

\subsubsection{Availability}

Any events or condition that cease production processes for a while (downtime loss) is included in the measurement of availability. Equipment/machine failures, shortages, change-over, and all factors that contribute to reducing actual operating time will be taken into account in the availability measurement. While change-over time is cannot be eliminated in most cases, it could be reduced to an acceptable length. In summary, availability is the ratio between actual operation time (which is planned operation time minus downtime) and planned operation time (Bulent, Tugwell, \& Greatbanks, 2000). So, availability can be calculated as follows:

Availability $(\%)=\frac{\text { Actual Operation Time }}{\text { Planned Operating Time }} \times 100 \%$

Total Shift Time - Planned Downtime

Actual Operating Time $=$

Planned Operating Time - Unplanned Downtime

\subsubsection{Performance}

In performance measurement, speed loss is calculated which involves any conditions that cause the production process to operate slower or less than the maximum optimal speed or planned speed for running. It is usually caused by operator inefficiency, machine wear, material discrepancy, misfeeds, etc. That means, performance is the ratio between actual operation time and planned operating time after the speed loss. Performance efficiency is described as the product's operating speed rate and net operating rate, while the operating speed rate for a machine is affected by the discrepancy between actual operating time and the ideal or expected operating time (Bulent, Tugwell, \& Greatbanks, 2000).

In the production, the minimum cycle time for a process that is expected to achieve under standard conditions for any given part is described as machine ideal cycle time. Thus, when the machine's ideal cycle time is multiplied by the total part/ number of outputs, the result will be the actual operating time. Since cycle time can be considered as a reciprocal of rate, performance can be calculated as follows:

Performance $=$

Machine Ideal Cycle Time $\times$ Number of Pieces Produced Planned Operation Time

Operating Speed Rate $=\frac{\text { Machine Ideal Cycle Time }}{\text { Actual Cycle Time }}$

Performance efficiency $=$

(Performance $\times$ Operating Speed Rate $) \times 100$

Or it can also be interpreted as follows:

$$
\text { Performance }=\frac{\text { Actual Output }}{\text { Theoretical Output }} \times 100 \%
$$

\subsubsection{Quality}

In the quality measurement, produced pieces or parts that do not fulfill the quality standard expected by the quality control, including rework or scrap, are considered as a quality loss. Quality measurement is used to indicate the ratio between defective products and the total production quantity. According to (Bulent, Tugwell, \& Greatbanks, 2000), the quality rate will only include defects in a certain stage of production or usually on specific machines and equipment. Therefore, the formula for quality measurement can be calculated as below

$$
\text { Quality }=\frac{\text { Good Pieces } \text { Produced }}{\text { Total Pieces } \text { Produced }}
$$

\subsubsection{Overall Equipment Effectiveness}

OEE is measured in the consideration of six big losses, which are practical can be calculated through availability, performance, and quality rate of the particular machine, line, plant, or whichever is the focus of the OEE calculation. OEE score can also indicate a complete measurement of machine efficiency. OEE can be formulated as follows:

$$
O E E=\text { Availability } \times \text { Performance } \times \text { Quality }
$$

Most big manufacturers that applied TPM or any lean programs have approximately $85 \%$ of OEE score, this also has been the standard for comparison and benchmarking as a world-class manufacturer (Amit, 2012). Also as stated by (Leflar, 1999) a worldwide study showed that $60 \%$ is the average of manufacturing plants and only be considered as a world-class company if the OEE reaches $85 \%$ or better with the three metrics score described in Table 1. 
Table 1. World Class OEE Standard

\begin{tabular}{|c|c|}
\hline OEE Factor & Word Class \\
\hline Availability & $90 \%$ \\
\hline Performance & $95 \%$ \\
\hline Quality & $99 \%$ \\
\hline OEE & $85 \%$ \\
\hline
\end{tabular}

\subsection{Capacity Planning}

The calculation for the estimated number of tools needed to manufacture predicted forecast product demand is described as capacity planning. In a common environment, the calculation uses an algebraic equation where the time required divided by the time available is equal to the number of tools needed (Jean Hood, Bermon, \& Barahona, 2003). In summary, capacity planning practices in determining production capacity and workforce are needed to fulfill demand in the supply chain. Capacity planning eases an organization to identify, measure bottlenecks, and create a better capacity design within a planned given period. Overcapacity will increase operating costs, while under capacity may conflict with strained resources and customer loss (Sule, Ogbadu, Ebenehi, \& Olukutun, 2012).

The capacity planning strategy is divided into longterm and short-term planning. Long-term strategy relates to overall stages of capacity including the size of the facility, while short-term planning relates to the probability of variations in the requirements of capacity and can be affected by irregular demand fluctuations, season, and random factors (Dejonckheere, S. M. Disney, \& Towill, 2014).

\subsection{Research Framework}

This section will explain the steps/methodology in this study from the observation to find the problem until make the conclusion and give the recommendation for the next studies. Each step will contain different objectives and methods to achieve the target and described in Figure 2.

To analyze the problems found in this research, supporting data is necessarily needed to validate and enhance the analysis. The data needed in this research are:

- Number of machines, machine profile, and machine specification

- Machine mapping, location, and operator distribution

- Number of scrap mold produced in daily production running and parts allocation

- Machine operating time, actual time, idle time, cleaning time, and change over time

- Output quality and machine capacity

After all the necessary data are being collected, the thing to do is to find the root cause of the problem stated in this research. This method can be done by filtering and selecting the most critical issue that has a huge impact in reducing the utilization of the Rapid Granulator machine. The data analysis will include:

- Analyze Day in the Life of (DILO) result to find the current ratio between the machine running and idle time in the total available time

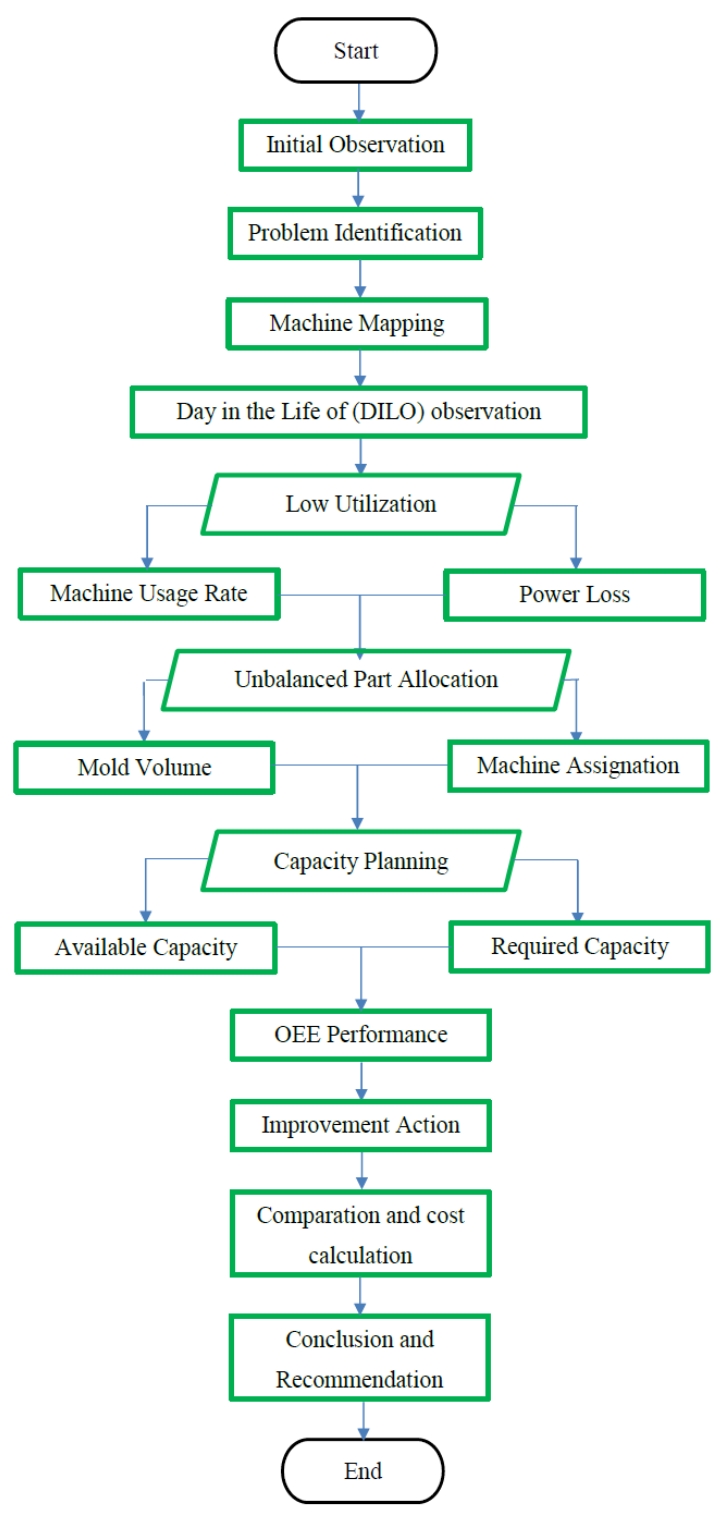

Figure 2. Research Framework

- Mapping and analyzing the layout of Rapid Granulator machine in Injection Molding area and possible issue in the current condition

- Calculate current OEE performance by selecting one of the production lines as the subject sample assuming the others line have the same condition

- Calculate the available capacity of each machine, specification and processing time for each type of plastic materials

- Compare machine capacity with part allocation and mold scrap produced in daily production running

After observing Rapid Granulator machine performance and collecting important data such as normal idle time, machine running time, and actual processing time, the red string and abnormality in the overall process can be found. Hence, to keep this research on track, research objectives have to be constructed as the key performance indicator of this research. The research objectives are: 
- Finding the root cause of the Rapid Granulator machine low utilization rate

- Generate a proper method for improvement to optimize Rapid Granulator machine usage

- Comparing machine performance before and after improvement for better understanding

- Calculating the possibility of cost-saving and other benefits of the proposed improvement

\section{Result and Discussion}

\subsection{Initial Situation}

After conducting observation and Gemba, it is found that Rapid Granulator machines have several abnormalities and issues. There is a huge gap in the period between each grinding process with the machine still turned on, thus wasting electricity and other resources. This has occurred because there is no guidance or standard of performance in operating Rapid Granulator machines. To make it worst, there is no proper usage schedule, poorly mapped operator, and even descriptive information regarding the number of machines, machines location, etc. are yet to be established. The initial situation can be seen as follows.

\subsubsection{Plastic Resins}

Plastic resins are made using heated hydrocarbons in a "cracking process". This process has the purpose to break down molecules into smaller particles called propylene or ethylene which can be found also in the crude oil refining method. Ethylene is then converted into polymer resins after undergoing the polymerization process. Furthermore, the compounds are later fused into chains called polymers and the combination of different polymers can result in a resin that can fulfill various functions that can be beneficial in the making of desired products such as bottles, toys, caps, etc. The final polymer/ plastic resins form is mainly produced as pellets or beads (Masoumi, Safavi Mohsen, \& Khani, 2012). The resins used are: Polypropylene (PP Trilene), Polyvinyl Chloride (PVC), Polyoxymethylene (Acetal), Nylon resin, Polypropylene Clear (PP Clear), Acrylonitrile Butadiene Styrene (ABS), K-resin, Polietilena (PE), Ethylene-vinyl Acetate (EVA), Polypropylene nonTrilene (PP Non-Trilene), and KINGFA

\subsubsection{Runner}

Runner is used to delivering plastic resin in the form of liquid into several mold cavities to make the desired plastic shape. While the plastic resin is being heated to maintain the molten state, the plastic resin will be injected from a nozzle using channels called runners and thus delivered into several different cavities at the same time. In a cold runner system, a plastic resin is injected through a sprue, a middle channel in which plastic went through the runners. The plastic resin then cools and solidifies both in runners and cavities. The excess plastic that is not included in the final part (runner) must be removed thus slowing down cycle time. As the most common system, the cold runner has long been practiced in PT. MT Indonesia as one of its standard operational procedures. As is described before, the runners also contain the same material as the product produced, thus before the grinding process, the runner will be categorized according to its material to prevent materials contamination.

\subsubsection{Machine Mapping}

PT. MT Indonesia had generated this machine mapping in the Injection Molding area, but the detailed description that focused on Rapid Granulator machines is yet to be established. Figure 3 will show the current layout of the Injection Molding area in PT. MT Indonesia and not the Rapid Granulator machines layout.

\subsubsection{Day in the Life of (DILO) Observation}

The selected operator is Naing which operates in the production lines A, B, and C with 16 Rapid Granulator machines. It is selected based on the highest average score of First Hour Output (FHO) that can be collected through Shift Schedule Control (SSC) in every production line. First Hour Output (FHO) indicates the number of good outputs in the first hour of production. Thus, the highest average FHO in one week of production will be selected as it represents the optimal condition for a machine to work with minimum disturbances. In the first column, the time interval will be calculated every 30 minutes while the second column indicates the activity that occurred during that period. The machine status will show whether the machine is turned Off or On. From Table 2, it can be concluded that the duration of the machine being turned on is 3 hours 30 minutes or equal to 210 minutes. While the actual operating time is only 2 hours or equal to 120 minutes. That means during one shift operating time, there is a power loss of 90 minutes machine runs where there is no regrind process with the machine still being left running.

The average power loss from usage is $35 \%$ and the average machine usage rate per-shift is only $23 \%$ (Table3). This indicates a very low utilization of Rapid Granulator machines which if not fixed will generate a huge loss (operating cost) and low machine performance. 


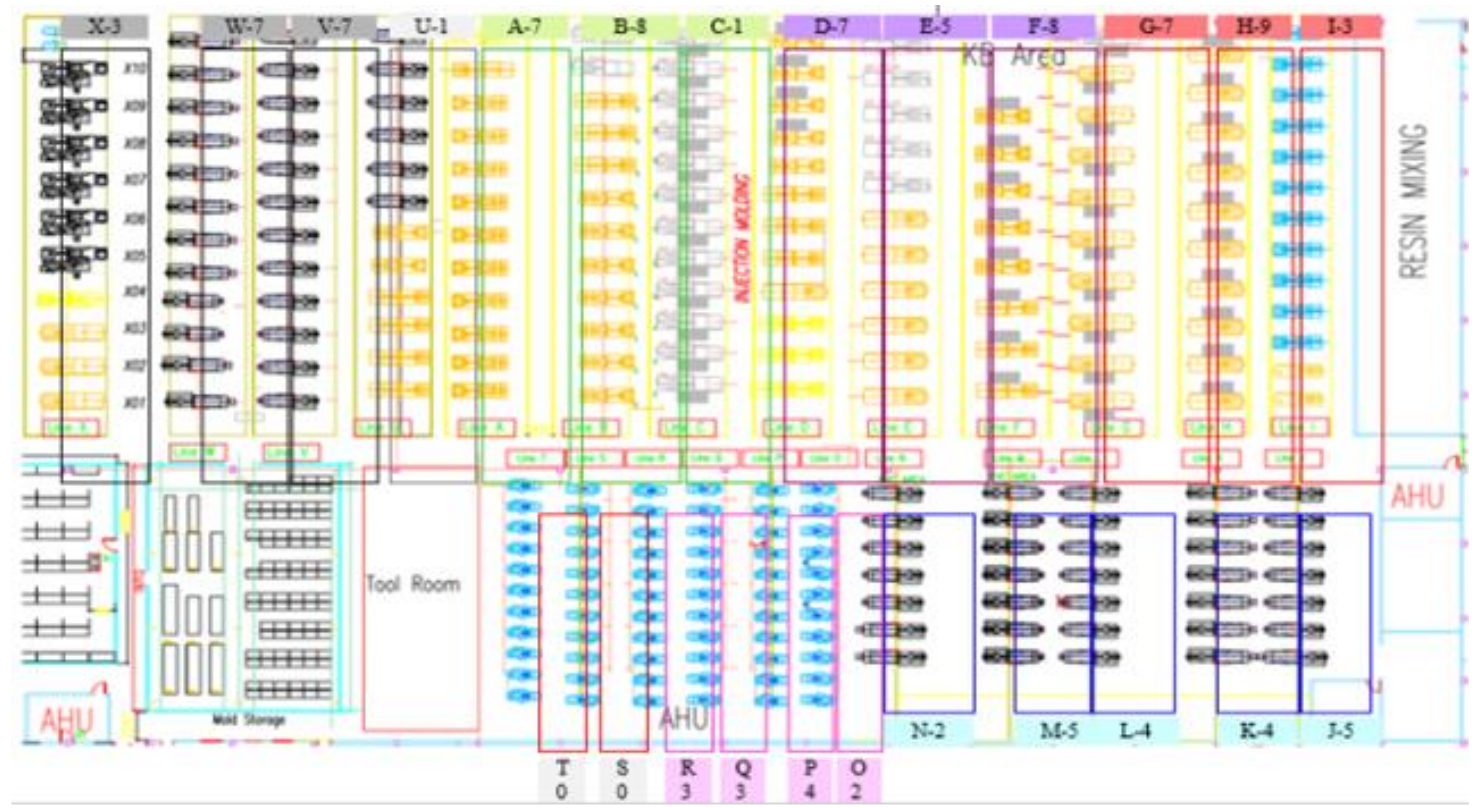

Figure 3. Injection Molding Layout

Table 2. DILO Observation

\begin{tabular}{clll}
\hline \multicolumn{1}{c}{ Time } & \multicolumn{1}{c}{ Activity } & \multicolumn{2}{c}{ Machine status } \\
\hline 07:10 - 08:30 & Regrind & On & Off \\
\hline 08:30 - 09:00 & Cleaning & On & Off \\
\hline 09:00 - 09:30 & No Activity & On & Off \\
\hline 09:30 - 10:00 & No Activity & On & Off \\
\hline 10:00 - 10:30 & Regrind & On & Off \\
\hline 10:30 - 11:00 & Regrind & On & Off \\
\hline 11:00 - 11:30 & No Activity & On & Off \\
\hline 11:30 - 12:00 & No Activity & On & Off \\
\hline 12:00 - 12:30 & No Activity & On & Off \\
\hline 12:30 - 13:00 & No Activity & On & Off \\
\hline 13:00 - 13:30 & No Activity & On & Off \\
\hline 13:30 - 14:00 & No Activity & On & Off \\
\hline 14:00 - 14:30 & Regrind & On & Off \\
\hline 14:30 - 15:00 & No Activity & On & Off \\
\hline 15:00 - 15:40 & Regrind & On & Off \\
\hline
\end{tabular}

Table 3. DILO Observation Result

\begin{tabular}{ccccccc}
\hline $\begin{array}{c}\text { Rapid } \\
\text { Number }\end{array}$ & $\begin{array}{c}\text { Mchn } \\
\text { Code }\end{array}$ & $\begin{array}{c}\text { Total } \\
\text { Regrind } \\
\text { Activity }\end{array}$ & $\begin{array}{c}\text { Total } \\
\text { Machine } \\
\text { On }\end{array}$ & $\begin{array}{c}\text { Power } \\
\text { Loss }\end{array}$ & $\begin{array}{c}\text { MC } \\
\text { Usage }\end{array}$ & Material \\
\hline $\begin{array}{c}\text { Rapid } \\
30\end{array}$ & B04 & 90 & 150 & $40 \%$ & $19 \%$ & ABS \\
\hline $\begin{array}{c}\text { Rapid } \\
20\end{array}$ & B06 & 30 & 60 & $50 \%$ & $6 \%$ & EVA \\
\hline $\begin{array}{c}\text { Rapid } \\
13\end{array}$ & B07 & 120 & 210 & $43 \%$ & $25 \%$ & PP \\
\hline $\begin{array}{c}\text { Rapid } \\
52\end{array}$ & B01 & 150 & 240 & $38 \%$ & $31 \%$ & EVA \\
\hline $\begin{array}{c}\text { Rapid } \\
46\end{array}$ & B11 & 180 & 300 & $40 \%$ & $38 \%$ & ABS \\
\hline $\begin{array}{c}\text { Rapid } \\
78\end{array}$ & B03 & 30 & 60 & $50 \%$ & $6 \%$ & PP \\
\hline $\begin{array}{c}\text { Rapid } \\
41\end{array}$ & B02 & 120 & 180 & $33 \%$ & $25 \%$ & PP \\
\hline $\begin{array}{c}\text { Rapid } \\
10\end{array}$ & B05 & 210 & 240 & $13 \%$ & $44 \%$ & PP \\
\hline $\begin{array}{c}\text { Rapid } \\
88\end{array}$ & B01 & 150 & 150 & $0 \%$ & $31 \%$ & PP \\
\hline $\begin{array}{c}\text { Rapid } \\
35\end{array}$ & A04 & 180 & 210 & $14 \%$ & $38 \%$ & ABS \\
\hline $\begin{array}{c}\text { Rapid } \\
22\end{array}$ & A07 & 90 & 120 & $25 \%$ & $19 \%$ & ABS \\
\hline $\begin{array}{c}\text { Rapid } \\
85\end{array}$ & A04 & 90 & 180 & $50 \%$ & $19 \%$ & ABS \\
\hline $\begin{array}{c}\text { Rapid } \\
01\end{array}$ & A02 & 30 & 60 & $50 \%$ & $6 \%$ & PVC \\
\hline
\end{tabular}

\begin{tabular}{ccccccc}
\hline $\begin{array}{c}\text { Rapid } \\
83\end{array}$ & A01 & 55 & 60 & $8 \%$ & $11 \%$ & PP \\
\hline $\begin{array}{c}\text { Rapid } \\
84\end{array}$ & A03 & 30 & 60 & $50 \%$ & $6 \%$ & ABS \\
\hline $\begin{array}{c}\text { Rapid } \\
85\end{array}$ & C12 & 90 & 180 & $50 \%$ & $19 \%$ & PP \\
\hline & & $\mathbf{1 6 4 5}$ & $\mathbf{2 4 6 0}$ & $\mathbf{3 5 \%}$ & $\mathbf{2 3 \%}$ & \\
\hline
\end{tabular}

\subsection{Data Analysis}

\subsubsection{Fishbone Diagram}

The root cause of low machine utilization can be seen found by using a fishbone diagram (Figure 4). The diagram shows the root cause generated from each factor consisting of man, material, machine, and method. The result is unbalanced operator distribution, variety of processing time, material shortage, no standard operating procedure, randomness in selecting a machine, and no flow chart and material handling route.

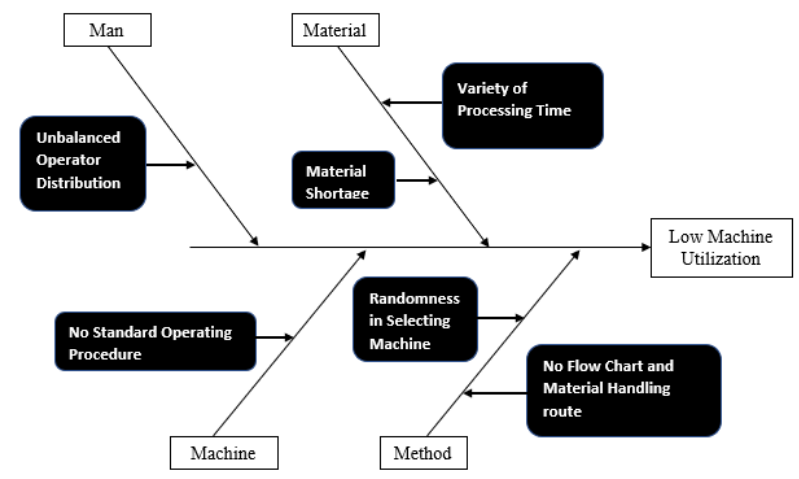

Figure 4. Fishbone Diagram

\subsubsection{Required Capacity}

PT. MT Indonesia has adopted a quarterly schedule system. That's mean the schedule is applied for every 4 months and the production rate will remain the same although the volume of material produced will not be the same each day/shift. Then, the auto planning runner data from the first week of September is selected as the sample of this calculation since the schedule will be more or less 
the same for the next four months. Since the first of September is on Tuesday, the calculation of the first week will only include 5 days, shows in Table 4.

Table 4. Total Runner Weight

\begin{tabular}{|c|c|c|c|c|c|}
\hline $\begin{array}{l}\text { Runner } \\
\text { Type }\end{array}$ & $\begin{array}{l}\text { Sum of } \\
\text { TUE }\end{array}$ & $\begin{array}{l}\text { Sum of } \\
\text { WED }\end{array}$ & $\begin{array}{l}\text { Sum of } \\
\text { THU }\end{array}$ & $\begin{array}{l}\text { Sum of } \\
\text { FRI }\end{array}$ & $\begin{array}{l}\text { Sum of } \\
\text { SAT }\end{array}$ \\
\hline ABS & 88.176 & 78.946 & 61.739 & 81.527 & 32.673 \\
\hline ACETAL & 212.329 & 264.939 & 261.004 & 230.373 & 159.074 \\
\hline EVA & 25.113 & 30.352 & 25.207 & 17.723 & 7.016 \\
\hline K-RESIN & 28.327 & 59.175 & 51.832 & 157.400 & 40.725 \\
\hline Nylon & 510.457 & 323.356 & 73.852 & 32.832 & 18.801 \\
\hline PE & 27.424 & 36.999 & 41.289 & 27.101 & 17.314 \\
\hline $\begin{array}{l}\text { PP Non- } \\
\text { trilene }\end{array}$ & 2.535 & 0.469 & 0.000 & 0.261 & 0.000 \\
\hline PP Clear & 98.451 & 72.138 & 102.482 & 105.696 & 29.381 \\
\hline $\begin{array}{l}\text { PP } \\
\text { Trilene }\end{array}$ & 370.967 & 388.242 & 323.153 & 246.018 & 161.174 \\
\hline PVC & 306.294 & 271.725 & 248.833 & 257.900 & 169.250 \\
\hline $\begin{array}{l}\text { Grand } \\
\text { Total }\end{array}$ & 1670.072 & 1526.341 & 1189.392 & 1156.831 & 635.409 \\
\hline
\end{tabular}

\subsubsection{Available Capacity}

The three types of machines have different specifications and disadvantages. In order to effectively calculate the available capacity, one type of Rapid Granulator machine has to be selected based on its capability and availability. In that matter, Rapid Granulator with 4 Blades is considered the best to regrind plastic waste produced in the Injection Molding area and will be used as the main machine to be used in the proposed improvement actions. The consideration of selecting Rapid Granulator with 4 Blades was based on:

1. The majority type with a total 82 number of machines (78\% from the total 105 machines).

2. Could work with any material used in PT. MT Indonesia (while Nylon, ABS, and EVA could not be processed in 3 Blades; and PVC could not be processed in 5 Blades).

3. In the current production process flow, 4-Blades Rapid Granulator machines fulfilled the role as the main regrinding machine (3-Blades and 5Blades are meant only to be a spare if all the 4Blades machines are full, which never happened before).

After selecting the Rapid Granulator machine with 4 Blades as the main regrinding machine, the available capacity calculation will be done for each runner type produced in the Injection Molding area. This is done because each runner type with different material has a different texture, size, and density thus making the regrinding time vary between runner types. Processing time measurement will be conducted in one of 4 BladesRapid Granulator machines with 10 different runner types. Steps to calculate the overall available capacity of all 4-Blades Rapid Granulator Machines:

The capacity pershift is generated by the multiplication of the number of machines assigned and the volume produced for each material. The formula can be seen as follow.

Capacity $/$ shift $=$ Num of Machines $\times$ Runner Prod $/$ Shif

One day of production running will include 3 shifts in total, so the capacity/day can be calculated as follow.
Capacity $/$ day $=$ Capacity $/$ shift $\times 3$

Since in this calculation, 5 days of 3 shift production running is used, the total capacity per day will be multiplicated by 5 .

Capacity $/$ week $=$ Capacity $/$ day $\times 5$

The result of an available capacity calculation is shown in Table 5.

Table 5. Total Available Capacity in One Week Production

\begin{tabular}{ccccc}
\hline Runner & \# MC & Kg/shift & Cap/Shift & Cap/Week \\
\hline PP Trilene & 20 & 54.75 & 1095 & 16425 \\
\hline PVC & 10 & 261 & 2610 & 39150 \\
\hline ACETAL & 2 & 146.025 & 292.05 & 4380.75 \\
\hline Nylon & 3 & 219 & 657 & 9855 \\
\hline PP clear & 10 & 139.875 & 1398.75 & 20981.25 \\
\hline ABS & 17 & 360 & 6120 & 91800 \\
\hline K-RESIN & 3 & 60 & 180 & 2700 \\
\hline PE & 4 & 81.375 & 325.5 & 4882.5 \\
\hline EVA & 11 & 249 & 2739 & 41085 \\
\hline KINGFA & 1 & 91.275 & 91.275 & 1369.125 \\
\hline PP (non trilene) & 1 & 125.7 & 125.7 & 1885.5 \\
\hline Total & $\mathbf{8 2}$ & $\mathbf{1 7 8 8}$ & $\mathbf{1 5 6 3 4 . 2 7 5}$ & $\mathbf{2 3 4 5 1 4 . 1 2 5}$
\end{tabular}

\subsubsection{Capacity Utilization}

The capacity utilization is very low as the total capacity utilization from the maximum available capacity is only $3 \%$, Table 6 . With this data, it can be known that the available capacity that all 4-Blades Rapid Granulator machines can offer significantly exceeds the required capacity of the runner being produced, so the conclusion is the number of Rapid Granulator machines is too many and thus providing room for improvement with a chance of cost and energy saving by reducing the number of machines.

Table 6. Capacity Utilization

\begin{tabular}{ccccc}
\hline Runner & $\begin{array}{c}\text { Available } \\
\text { Capacity }\end{array}$ & $\begin{array}{c}\text { Required } \\
\text { Capacity }\end{array}$ & Gap & $\begin{array}{c}\text { Capacity } \\
\text { Utlization }\end{array}$ \\
\hline $\begin{array}{c}\text { PP } \\
\text { Trilene }\end{array}$ & 16425 & 1489.55 & 14935.45 & $9 \%$ \\
\hline PVC & 39150 & 1254 & 37896 & $3 \%$ \\
\hline ACETAL & 4380.75 & 1127.71 & 3253.04 & $26 \%$ \\
\hline Nylon & 9855 & 959.29 & 8895.71 & $10 \%$ \\
\hline PP clear & 20981.25 & 408.14 & 20573.11 & $2 \%$ \\
\hline ABS & 91800 & 343.06 & 91456.94 & $0 \%$ \\
\hline K-RESIN & 2700 & 337.45 & 2362.55 & $12 \%$ \\
\hline PE & 4882.5 & 150.12 & 4732.38 & $3 \%$ \\
\hline EVA & 41085 & 105.41 & 40979.59 & $0 \%$ \\
\hline $\begin{array}{c}\text { PP }(\text { non } \\
\text { trilene) }\end{array}$ & 3771 & 3.26 & 3767.74 & $0 \%$ \\
\hline Total & $\mathbf{2 3 5 0 3 0 . 5}$ & $\mathbf{6 1 7 7 . 9 9}$ & $\mathbf{2 2 8 8 5 2 . 5 1}$ & $\mathbf{3 \%}$ \\
\hline
\end{tabular}

\subsubsection{Availability}

Using Eq. 1, then applied to the data sample as can be seen in Table 7 . The average availability will be used as a benchmark of the current condition of the 4-Blades Rapid Granulator machine's availability. The current machine average availability is $23 \%$. There are three machines with the lowest availability percentage which are B06, B03, and A02 with only $7 \%$ of availability. 
Table 7. Machine Availability

\begin{tabular}{ccccc}
\hline No & Machine & $\begin{array}{c}\text { Actual } \\
\text { Operating } \\
\text { Time } \\
\text { (Minutes) }\end{array}$ & $\begin{array}{c}\text { Planned } \\
\text { Operating } \\
\text { Time } \\
\text { (Minutes) }\end{array}$ & Availability \\
\hline 1 & B04 & 90 & 450 & $20 \%$ \\
\hline 2 & B06 & 30 & 450 & $7 \%$ \\
\hline 3 & B07 & 120 & 450 & $27 \%$ \\
\hline 4 & B01 & 150 & 450 & $33 \%$ \\
\hline 5 & B11 & 180 & 450 & $40 \%$ \\
\hline 6 & B03 & 30 & 450 & $7 \%$ \\
\hline 7 & B02 & 120 & 450 & $27 \%$ \\
\hline 8 & B05 & 210 & 450 & $47 \%$ \\
\hline 9 & B01 & 150 & 450 & $33 \%$ \\
\hline 10 & A04 & 180 & 450 & $40 \%$ \\
\hline 11 & A07 & 90 & 450 & $20 \%$ \\
\hline 12 & A04 & 90 & 450 & $20 \%$ \\
\hline 13 & A02 & 30 & 450 & $7 \%$ \\
\hline 14 & A01 & 55 & 450 & $12 \%$ \\
\hline 15 & A03 & 30 & 450 & $7 \%$ \\
\hline 16 & B04 & 90 & 450 & $20 \%$ \\
\hline \multicolumn{5}{r}{ Average Availability } \\
\hline
\end{tabular}

\subsubsection{Performance}

In these metrics, theoretical output and the machine's actual output have to be calculated. Since the actual output has been collected in the DILO observation, the performance can be calculated by using Eq. 7. Using the formula, each machine's performance is calculated. The lowest performance is held by machine A01 with a score of $2 \%$, while the highest performance is held by machine B07 with a score of $16 \%$. The full performance calculation can be seen in Table 8 .

Table 8. Machine Performance

\begin{tabular}{ccccc}
\hline No & Machine & $\begin{array}{c}\text { Theoritical } \\
\text { Output } \\
\text { (kg/hour) }\end{array}$ & $\begin{array}{c}\text { Actual } \\
\text { Output } \\
\text { (kg/hour) }\end{array}$ & Performance \\
\hline 1 & B04 & 48 & 2.37 & $5 \%$ \\
\hline 2 & B06 & 33.2 & 4.1 & $12 \%$ \\
\hline 3 & B07 & 7.3 & 1.2 & $16 \%$ \\
\hline 4 & B05 & 7.3 & 0.99 & $14 \%$ \\
\hline 5 & B11 & 48 & 6 & $13 \%$ \\
\hline 6 & B03 & 7.3 & 0.54 & $7 \%$ \\
\hline 7 & B02 & 7.3 & 0.21 & $3 \%$ \\
\hline 8 & A06 & 8 & 1 & $13 \%$ \\
\hline 9 & B01 & 33.2 & 3.33 & $10 \%$ \\
\hline 10 & A05 & 8 & 0.42 & $5 \%$ \\
\hline 11 & A07 & 48 & 2 & $4 \%$ \\
\hline 12 & A04 & 48 & 5.1 & $11 \%$ \\
\hline 13 & A02 & 34.8 & 1.6 & $5 \%$ \\
\hline 14 & A01 & 7.3 & 0.11 & $2 \%$ \\
\hline 15 & A03 & 48 & 3 & $6 \%$ \\
\hline 16 & C12 & 7.3 & 450 & $6 \%$ \\
\hline \multicolumn{7}{r}{ Average Performance } & $\mathbf{8 \%}$ \\
\hline
\end{tabular}

\subsubsection{Quality}

In the plastic regrind process, the runner is processed by a Rapid Granulator machine to be a smaller particle or in a shredded form. Thus, the output of crumbled plastic resin cannot be identified nor checked for its quality. All the Rapid Granulator machine's output is considered as the final product without defect and will be fully used as a recycled material. With this information, the quality metrics cannot be considered in the Rapid Granulator OEE measurement or can be assumed that $100 \%$ of the output is a good output (therefore the quality measurement will be assumed as $100 \%)$.

\subsubsection{Overall Equipment Effectiveness}

After the three metrics are generated, the OEE calculation can be done with Eq 9. The result will be shown below.

$$
\begin{gathered}
O E E=23 \% \times 8 \% \times 100 \% \\
O E E=1.8 \%
\end{gathered}
$$

Based on the calculation, the Overall Equipment Effectiveness (OEE) of Rapid Granulator machines is $1.8 \%$ with $23 \%$ of availability, $8 \%$ of performance, and $100 \%$ of quality. This number is very low compared to the world standard of appropriate OEE score which is $85 \%$. This calculation also shows that the main cause of the low OEE percentage is low availability and machine usage.

\subsection{Proposed Improvement}

From the data analysis before, it can be concluded that Rapid Granulator machines in the Injection Molding area have a low utilization rate, a huge gap between available and required capacity, and low machine performance that is indicated with the OEE score. Therefore, several proposed improvement actions can be done to increase Rapid Granulator machines utilization and performance. The method will be described below.

\subsubsection{Machine Reduction}

From the data analysis and calculation conducted before, it can be concluded that there are too many Rapid Granulator machines available in the Injection Molding area. This statement is supported by the low percentage of utilization rate, a huge gap between available and required capacity, and low availability in OEE performance calculation. The calculation for the optimal number of machines will be shown in Table 9-11.

In this case (when the data are being collected), PT. MT Indonesia has run rates of 1.25 million toys per year. But, in the following year, PT. MT Indonesia will increase its production rate up to 1.8 million toys per year, thus the calculation will be done with the 1.8 run rate. 
Table 9. Output vs Capacity

\begin{tabular}{ccccc}
\hline Runner & Daily & $\begin{array}{c}\text { Shiftly/ } \\
\text { Run Rate } \\
\mathbf{1 . 2 5}\end{array}$ & $\begin{array}{c}\text { Shiftly/ } \\
\text { Run Rate } \\
\mathbf{1 . 8}\end{array}$ & Capacity/h \\
\hline PP Trilene & 297.9 & 99.3 & 143.00 & 7.3 \\
\hline PVC & 250.8 & 83.6 & 120.38 & 34.8 \\
\hline ACETAL & 225.5 & 75.2 & 108.26 & 19.47 \\
\hline Nylon & 191.9 & 64.0 & 92.09 & 29.2 \\
\hline PP clear & 81.6 & 27.2 & 39.18 & 18.65 \\
\hline ABS & 68.6 & 22.9 & 32.93 & 48 \\
\hline K-RESIN & 67.5 & 22.5 & 32.40 & 8 \\
\hline PE & 30.0 & 10.0 & 14.41 & 10.85 \\
\hline EVA & 21.1 & 7.0 & 10.12 & 33.2 \\
\hline KINGFA & 19.7 & 6.6 & 9.46 & 12.17 \\
\hline $\begin{array}{c}\text { PP (non } \\
\text { trilene) }\end{array}$ & 0.7 & 0.2 & 0.31 & 16.67 \\
\hline Total & $\mathbf{1 2 5 5 . 3}$ & $\mathbf{4 1 8 . 4}$ & $\mathbf{6 0 2 . 5 5}$ & \\
\hline
\end{tabular}

Table 10. Total Hour Needed per Runner Type (Shorted by Total Hour Needed)

\begin{tabular}{ccccc}
\hline Runner & $\begin{array}{c}\text { Time } \\
\text { Needs }\end{array}$ & Cleaning & $\begin{array}{c}\# \\
\text { Color }\end{array}$ & $\begin{array}{c}\text { Total Hour } \\
\text { Needs }\end{array}$ \\
\hline PP Trilene & 19.59 & 7.00 & 42 & 26.59 \\
\hline PVC & 3.46 & 8.50 & 51 & 11.96 \\
\hline Acetal & 5.56 & 3.17 & 19 & 8.73 \\
\hline Nylon & 3.15 & 0.67 & 4 & 3.82 \\
\hline PP clear & 2.10 & 1.33 & 8 & 3.43 \\
\hline ABS & 0.69 & 6.17 & 37 & 6.85 \\
\hline K-Resin & 4.05 & 0.83 & 5 & 4.88 \\
\hline PE & 1.33 & 1.67 & 10 & 2.99 \\
\hline EVA & 0.30 & 1.50 & 9 & 1.80 \\
\hline Kingfa & 0.78 & 1.83 & 11 & 2.61 \\
\hline PP non- & 0.02 & 1.33 & 8 & 1.35 \\
Trilene & & & & \\
\hline Total & 19.59 & 7.00 & 42 & 26.59 \\
\hline
\end{tabular}

By dividing the number of total hours needs by the standard shift hour which is 7.5 , the optimal machine number for each runner type can be found in Table 11 .

Table 11. Optimal Number of Rapid Granulator Machine

\begin{tabular}{ccc}
\hline Runner & Total Hour Needs & \# Of Machine needed \\
\hline PP Trilene & 26.59 & 4 \\
\hline PVC & 11.96 & 2 \\
\hline ACETAL & 8.73 & 2 \\
\hline Nylon & 3.82 & 1 \\
\hline PP clear & 3.43 & 1 \\
\hline ABS & 6.85 & 1 \\
\hline K-RESIN & 4.88 & 1 \\
\hline PE & 2.99 & 1 \\
\hline EVA & 1.80 & 1 \\
\hline KINGFA & 2.61 & 1 \\
\hline PP (non trilene) & 1.35 & 1 \\
\hline Total & $\mathbf{2 6 . 5 9}$ & $\mathbf{1 6}$ \\
\hline \multicolumn{2}{c}{ Spare (50\%) } & $\mathbf{8}$ \\
\hline Grand Total & $\mathbf{2 4}$
\end{tabular}

The optimal number of machines to complete all the required output within a shift is 16 machines. This number will be increased by $50 \%$ due to PT. MT Indonesia's policy regarding the minimum percentage of spare. The total number of machines generated in the final improvement action will be 24 machines.

\subsubsection{Overall Equipment Effectiveness After Machine Reduction}

Since the machine reduction has not been done in PT. MT Indonesia, a trial test has been done in order to analyze future OEE. In this test, only 16 machines are used in one shift production running to capture the approximate OEE score after conducting machine reduction as proposed. The data collection will now be using SSC (Shift Schedule Control) that has been placed to the assigned 16 machines to ease the OEE calculation. The Shift Schedule Control has the purpose of capturing real performance (output, hour, material, etc.) that is filled by operators throughout the shift. As it can be seen in Table 12, the three metrics of availability, performance, and quality are calculated for each machine.

The Overall Equipment Effectiveness before and after improvement comparison can be seen in Table 13 . As the data shows, there is a huge increase in OEE score from $1.8 \%$ to $39 \%$ (increasing $2048.4 \%$ ). The availability metrics increasing from $23 \%$ to $87 \%$ because of the higher actual operating time for each machine to process the desired output. The performance metrics also increasing from $8 \%$ to $45 \%$ because of the denser runner allocation for each machine thus affecting higher actual output.

Table 12. OEE After Machine Reduction

\begin{tabular}{ccccc}
\hline Rapid Number & Availability & Performance & Quality & OEE \\
\hline 1 & $84 \%$ & $61 \%$ & $99 \%$ & $51 \%$ \\
\hline 2 & $91 \%$ & $54 \%$ & $99 \%$ & $49 \%$ \\
\hline 3 & $71 \%$ & $99 \%$ & $99 \%$ & $70 \%$ \\
\hline 4 & $80 \%$ & $78 \%$ & $99 \%$ & $62 \%$ \\
\hline 5 & $81 \%$ & $25 \%$ & $99 \%$ & $20 \%$ \\
\hline 6 & $89 \%$ & $22 \%$ & $99 \%$ & $19 \%$ \\
\hline 7 & $92 \%$ & $30 \%$ & $99 \%$ & $27 \%$ \\
\hline 8 & $82 \%$ & $40 \%$ & $99 \%$ & $33 \%$ \\
\hline 9 & $86 \%$ & $89 \%$ & $99 \%$ & $76 \%$ \\
\hline 10 & $90 \%$ & $52 \%$ & $99 \%$ & $46 \%$ \\
\hline 11 & $93 \%$ & $25 \%$ & $99 \%$ & $23 \%$ \\
\hline 12 & $91 \%$ & $37 \%$ & $99 \%$ & $33 \%$ \\
\hline 13 & $89 \%$ & $45 \%$ & $99 \%$ & $40 \%$ \\
\hline 14 & $97 \%$ & $12 \%$ & $99 \%$ & $11 \%$ \\
\hline 15 & $86 \%$ & $37 \%$ & $99 \%$ & $31 \%$ \\
\hline 16 & $87 \%$ & $14 \%$ & $99 \%$ & $12 \%$ \\
\hline & $\mathbf{8 7 \%}$ & $\mathbf{4 5 \%}$ & $\mathbf{9 9 \%}$ & $\mathbf{3 8 \%}$ \\
\hline
\end{tabular}

Table 13. OEE Comparison

Current Condition After Improvement

\begin{tabular}{lcc} 
& Current Condition & After Improvement \\
\hline Availability & $23 \%$ & $87 \%$ \\
\hline Performance & $8 \%$ & $45 \%$ \\
\hline Quality & $100 \%$ & $100 \%$ \\
\hline OEE & $1.8 \%$ & $39 \%$ \\
\hline \% Improvement & & $2048.4 \%$ \\
\end{tabular}

Although the Overall Equipment Effectiveness of Rapid Granulator machines after improvement is increasing approximately $2048 \%$ from the current condition, it is still far from the world-class standard which is $85 \%$. There are several reasons why the OEE of Rapid Granulator cannot reach $85 \%$ of the OEE score, which are: 
1. It is not a primary machine, which means its input is based on the number of runners produced in the Injection Molding Process which varies in volume, colors, and type thus the machine performance will be different for each period and the available capacity will not fully be used because of the limitation by the Injection Molding maximum capacity.

2. The regrind process doesn't have/ doesn't need to have a schedule. The operator would do the regrind process based on the runner produced with uncertainty number of cleaning process throughout the available operating time.

3. The total number of machines used is based on the maximum capacity needed if by any means all the color from each runner is produced in a single shift period, thus making the theoretical output the upper limit and lower performance metrics during normal conditions.

\subsubsection{Cost savings}

The cost saving can be calculated by comparing the power consumption of Rapid Granulator machines before and after improvement. The energy consumption per machine is $2.2 \mathrm{~kW} /$ hour and the number of machines is reduced from 105 to 24 (reducing 81 number of machines). As it can be seen in Table 14, the electrical consumption per year to operate the current 105 Rapid Granulator machines for 300 operating days is $1,559,250$ $\mathrm{kWh}$. Meanwhile, the proposed improvement action can reduce as much as $1,202,850 \mathrm{kWh}$ in one year $(77 \%$ reduction) and saved operating costs as much as USD 150,356 per year (as $1 \mathrm{kWh}$ equals USD 0.125 ).

\begin{tabular}{|c|c|c|c|}
\hline Item & Unit & Existing & Future \\
\hline \multirow[t]{2}{*}{ Electrical cons./unit } & $\mathrm{kW}$ & & \\
\hline & & 2.2 & 2.2 \\
\hline \multirow[t]{2}{*}{ Total unit } & Pcs & & \\
\hline & & 105.0 & 24.0 \\
\hline \multirow[t]{2}{*}{ Total Running Hour per day } & hour & & \\
\hline & $\mathrm{s}$ & 22.5 & 22.5 \\
\hline \multirow[t]{2}{*}{ Total Electrical cons. / days } & $\mathrm{kWh}$ & & \\
\hline & & $5,197.5$ & $1,188.0$ \\
\hline \multirow[t]{2}{*}{ Total Electrical cons. / Year } & $\mathrm{kWh}$ & & \\
\hline & & $1,559,250$ & 356,400 \\
\hline Total Electrical saving / Year & $\mathrm{kWh}$ & & $1,202,850$ \\
\hline Total Electrical saving / Year & USD & & 150,356 \\
\hline
\end{tabular}

\subsubsection{Standard Operating Procedure}

To make the Rapid Granulator machine usage more effective, Standard Operating Procedure is needed to ensure the Operator knows the optimal method to handle it. The SOP will be included as follows.

\section{A. Machine Assignation}

To minimize over-change time and reduce miss locating, each machine number has to be assigned to a specific workload which can be seen in Table 15. In this table, the first 8 machines will be assigned fully for a certain material while the other 8 will be combined by a different material with a $66-33$ ratio of proportion. This proportion is generated from the required capacity calculation as there is a runner type with lower capacity needs resulting in the machine still have some available time even after it processed the particular material.

Table 15. Runner Type Proportion per Machine

\begin{tabular}{ccc}
\hline Rapid Number & Runner Type & $\begin{array}{c}\text { Material } \\
\text { Percentage }\end{array}$ \\
\hline 1 & PP Trilene & $100 \%$ \\
\hline 2 & PP Trilene & $100 \%$ \\
\hline 3 & PP Trilene & $100 \%$ \\
\hline 4 & PP Trilene & $100 \%$ \\
\hline 5 & PVC & $100 \%$ \\
\hline 6 & PVC & $100 \%$ \\
\hline 7 & Acetal & $100 \%$ \\
\hline 8 & Acetal & $100 \%$ \\
\hline 9 & Nylon, Acetal & $66 \%, 33 \%$ \\
\hline 10 & PP clear, Acetal & $66 \%, 33 \%$ \\
\hline 11 & ABS, PVC & $66 \%, 33 \%$ \\
\hline 12 & K-RESIN, PVC & $66 \%, 33 \%$ \\
\hline 13 & PE, PP Trilene & $66 \%, 33 \%$ \\
\hline 14 & EVA, PP Trilene & $66 \%, 33 \%$ \\
\hline 15 & KINGFA, PP Trilene & $66 \%, 33 \%$ \\
\hline 16 & PP (non trilene), PP Trilene & $66 \%, 33 \%$ \\
\hline
\end{tabular}

B. Operator Distribution and Flow Chart

It is known six operators have to handle the overall Rapid Granulator machines, Table 16. In this improvement, those six operators will be distributed based on the volume of material input and the frequency of material handling from the staging area. The distribution of operators with the machine assigned can be seen in Table 17.

Table 16. Previous Machines Assigned per Operator

\begin{tabular}{cccc}
\hline No & Operator & Total Machine & Production Lines \\
\hline 1 & Manijan & 20 & J-K-L-M-N \\
\hline 2 & Naing & 16 & A-B-C \\
\hline 3 & Peni & 16 & U-V-W-X \\
\hline 4 & Rahmat & 20 & D-E-F \\
\hline 5 & Rojak & 19 & G-H-I \\
\hline 6 & Wahyu & 14 & O-P-Q-R \\
\hline & Total & $\mathbf{1 0 5}$ & 22 Lines \\
\hline
\end{tabular}

Table 17. Runner Type Proportion per Machine

\begin{tabular}{cccc}
\hline No & Operator & Total Machine & Rapid Number \\
\hline 1 & Manijan & 2 & 1,2 \\
\hline 2 & Naing & 2 & 3,4 \\
\hline 3 & Peni & 2 & 5,6 \\
\hline 4 & Rahmat & 2 & 7,8 \\
\hline 5 & Rojak & 4 & $9,10,11,12$ \\
\hline 6 & Wahyu & 4 & $13,14,15,16$ \\
\hline & Total & $\mathbf{1 6}$ & $\mathbf{1 6}$ \\
\hline
\end{tabular}

This operator will be mentioned as Material Handler which has the job responsibilities as described in the flow chart in Figure 5. 


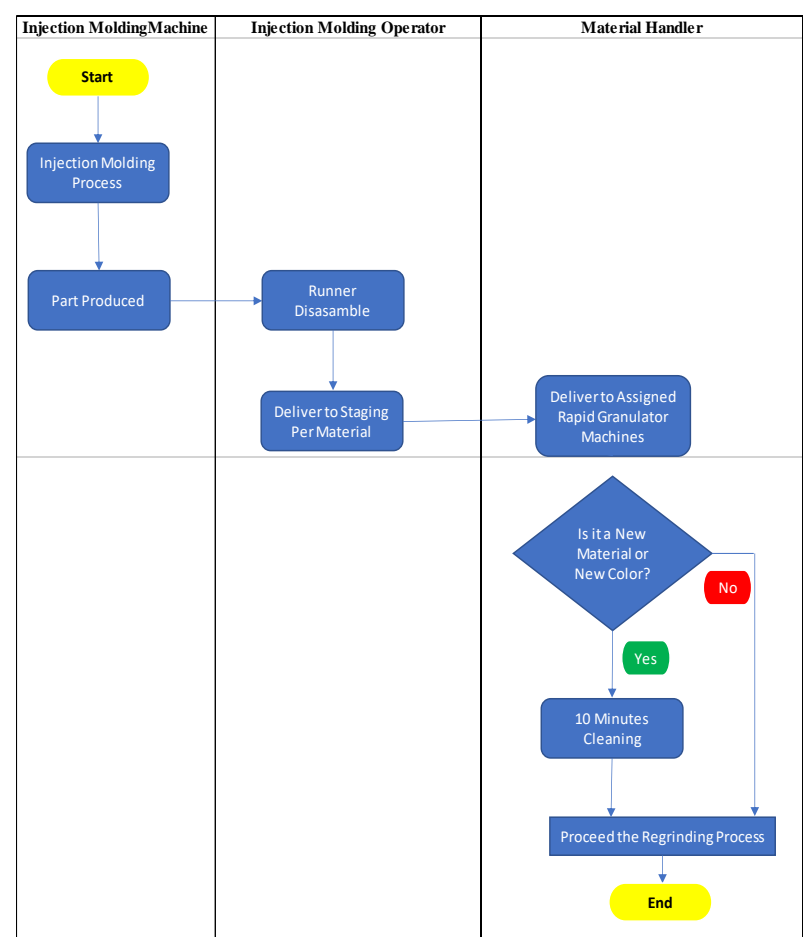

Figure 5. Flow Chart Rapid Granulator Operators/ Material Handler

\section{Conclusion}

Based on the data, the current machine utilization rate is $23 \%$. This number is considered far below the average of PT. MT standard at $85 \%$ for machine utilization rate. Using the DILO observation data, the Overall Equipment Effectiveness of Rapid Granulator machines is calculated to be only $1.8 \%$ with $23 \%$ of availability, $8 \%$ of performance, and $100 \%$ of quality. Machine mapping is generated with the purpose to observe Rapid Granulator's current layout which at the same time provides critical information consisting of the number of machines, operator distribution, runner produced per machine, and machine assignation. With this information, the required and available capacity can be calculated as it's found that there is a huge gap of $228852.51 \mathrm{kgs}$ in a one-week operating schedule which resulting only $3 \%$ of available capacity is being used in PT. MT Indonesia. Thus, it can be concluded that the root cause of Rapid Granulator machines' low utilization rate is because of the excessive number of Rapid Granulator machines used and remotely low material input.

Proposed improvement action could be done by reducing the number of machines from the total 105 machines to only 24 machines (of 4-Blades Rapid Granulator only). This action will provide a significant increase in Overall Equipment Effectiveness to $39 \%$ with $87 \%$ availability/machine usage rate, $45 \%$ of performance, and $100 \%$ of quality. In addition, costsaving from the reduction of power consumed by Rapid Granulator machines from $1,559,250 \mathrm{kWh}$ per year to only $356,400 \mathrm{kWh}$ per year. Resulting from the total electrical saving per year of $1,202,850 \mathrm{kWh}$ with the calculated cost saving to be USD 150,356 per year.

\section{References}

Amit, K. G. (October de 2012). OEE Improvement by TPM Implementation: A Case Study. International Journal of IT, Engineering and Applied Sciences Research (IJIEASR), I(1).

Bulent, D., Tugwell, P., \& Greatbanks, R. (2000). Emerald Article: Overall equipment effectiveness as a measure of operational improvement - A practical analysis. International Journal of Operations \& Production Management, 20(12), 1488-1502.

C. Andersson, M. Bellgran, On the complexity of using performance measures: Enhancing sustained production improvement capability by combining OEE and productivity, Journal of Manufacturing Systems, Volume 35, 2015

Dejonckheere, J., S. M. Disney, M. L., \& Towill, D. R. (14 de October de 2014). The dynamics of aggregate planning. Production Planning \& Control: The Management of Operations. DOI: http://dx.doi.org/10.1080/09537280310001621 967

Henrik, K., Kurt, S., \& Henning, U. (18 de June de 2013). Patente $n^{\circ}$ US 8,464,973 B2. United States.

Jean Hood, S., Bermon, S., \& Barahona, F. (May de 2003). Capacity Planning Under Demand Uncertainty for Semiconductor Manufacturing. IEEE TRANSACTIONS ON SEMICONDUCTOR MANUFACTURING, 16(2).

Kutucuoglu, K., Hamali, J., Irani, Z. J., \& Sharp, M. (2001). A framework for managing maintenance using performance measurement systems. International Journal of Operations \& Production Management.

Leflar, J. (1999). TPM at Hewlett-Packard. 10th Total Productive Maintenance Conference.

Martomo, Zenithia Intan and Laksono, Pringgo Widyo. (2018), "Analysis of total productive maintenance (TPM) implementation using overall equipment effectiveness (OEE) and six big losses: A case study", AIP Conference Proceedings 1931, 030026.

Masoumi, H., Safavi Mohsen, S., \& Khani, Z. (2012). Identification and Classification of Plastic Resins using Near-Infrared Reflectance Spectroscopy. International Journal of Mechanical and Industrial Engineering(6).

Nakajima, S. (1988). Introduction to Total Productive Maintenance (TPM). Productivity Press. 
Subramaniam, S. K., Husin, S. H., Yusop, Y., \& Hamidon, A. (2008). Machine efficiency and manpower utilization on production lines. Proceedings of the 8th WSEAS Int. Conf. on ELECTRONICS, HARDWARE, WIRELESS, and OPTICAL COMMUNICATIONS.

Sule, J. G., Ogbadu, D., Ebenehi, E., \& Olukutun, G. A. (2012). Capacity Planning and Its Implications on the Infrastructural Development Needs of Some Selected Higher Institutions in the Eastern

Senatorial District of Kogi State. Global Journal of Management and Business Research,
12(23).
Obtenido
de

https://globaljournals.org/GJMBR_Volume12/

8-Capacity-Planning-and-Its-Implications.pdf

Ward, J. (19 de May de 2017). The Benefits of Machine Mapping. (Advanced Machine Reliability Resource Inc.) Obtenido de https://amrri.com/latest-news/the-benefits-ofmachine-mapping/. 